\title{
Currently Married Women with an Unmet Need for Contraception in Minia Governorate, Egypt: Profile and Determinants
}

\author{
Ebtesam Esmail Hassan', Eman Ramadan Ghazawy ${ }^{1}$, Naglaa Mohammed Amein ${ }^{2}$ \\ ${ }^{1}$ Public Health and Preventive Medicine Department, Faculty of Medicine, Minia University, Minia, Egypt \\ ${ }^{2}$ Community Health Nursing Department, Faculty of Nursing, Minia University, Minia, Egypt \\ Email: *emanghazawy@yahoo.com
}

How to cite this paper: Hassan, E.E., Ghazawy, E.R. and Amein, N.M. (2017) Currently Married Women with an Unmet Need for Contraception in Minia Governorate, Egypt: Profile and Determinants. Open Journal of Preventive Medicine, 7 , 225-234.

https://doi.org/10.4236/ojpm.2017.711018

Received: September 30, 2017

Accepted: November 6, 2017

Published: November 9, 2017

Copyright $\odot 2017$ by authors and Scientific Research Publishing Inc. This work is licensed under the Creative Commons Attribution International License (CC BY 4.0).

http://creativecommons.org/licenses/by/4.0/

(c) (i) Open Access

\begin{abstract}
Background: Understanding the magnitude of unmet contraceptive need and the underlying determinants will help the programs and services to respond effectively. Aim: Identify the prevalence and determinants of unmet contraceptive need among married women in the childbearing period in Minia Governorate. Methods: Community-based cross-sectional study was done among married women of child bearing age (18 - 49 years). Total 534 study participants were selected randomly and interviewed by using pretested structured questionnaire. Results: Overall level of unmet need was $12.7 \%$. Women age $>35$ years old were about three times (adjusted OR $=2.88,95 \%$ CI: 1.13 - 7.35) more likely to have unmet need for family planning compared to younger women. Women who had more children (adjusted OR $=1.32,95 \%$ CI: 1.04 - 1.67), more female offspring (adjusted OR $=1.37$, 95\% CI: 1.09 1.65), and women whose partner had non-supportive attitude towards family planning (adjusted OR $=2.96,95 \%$ CI: 1.53 - 5.72) were more likely to have unmet need. Conclusion: The prevalence of unmet need of family planning among women in Minia Governorate remains high. Therefore, family planning programs that cover the older woman's need for limiting and that focus on couples could be useful in reducing the rate of unmet need.
\end{abstract}

\section{Keywords}

Family Planning, Unmet Need, Determinants

\section{Introduction}

Increasing awareness of family planning methods, identifying potential demand for contraception and facilitating access to them would significantly improve ma- 
ternal and child health and ultimately reduce maternal deaths. Although advances in family planning have been achieved globally, the unmet needs for planning continue to increase and become a serious problem in developing countries [1].

Generally, women considered having an unmet need if they are sexually active and want to avoid becoming pregnant but are not using contraception. According to the revised unmet need definition by Bradley et al (2015), "women are considered to have unmet need for spacing if they are; at risk of becoming pregnant, not using contraception, and either do not want to become pregnant within the next two years, or are unsure if or when they want to become pregnant; pregnant with a mistimed pregnancy; or postpartum amenorrheic for up to two years following a mistimed birth and not using contraception" [2].

According to an estimate, 225 million women in developing countries had an unmet need for contraception. Annually, an estimated 74 million unintended pregnancies occur in developing regions, most of them are women using no contraception or a traditional method. If all unmet need for modern methods were met, 70,000 deaths from pregnancy-related causes could be prevented [3].

Many studies found that women with unmet need for contraception represent a significant portion of all married women of reproductive age [2] [4] [5]. It was estimated that $17 \%$ of married women in the developing world still have an unmet need for contraception [6].

According to the Egyptian Ministry of Population and Health's statistics, 8 out of 10 married women wanted no additional children, there is still a sizable proportion did not use contraceptives [7].

In order to satisfy women's unmet need for contraception, it is crucial to understand and identify the causes and underlying factors of unmet need, so that programs and services can respond effectively. Unfortunately, there are few published works about the magnitude and determinants of unmet need in Upper Egypt. Hence, this study aims to measure the prevalence and determine the reasons for unmet contraceptive need among married women in the childbearing period.

\section{Methodology}

\subsection{Study Design and Population}

A cross-sectional community-based study was conducted targeting married women of child-bearing age (18 - 49 years old) living in Minia district during the period from September to December 2016.

Minia Governorate is one of Upper Egypt's Governorates located about 240 $\mathrm{Km}$ to the south of Cairo; Minia district was randomly selected from the nine districts in Minia governorate. Minia city and Damares village were randomly chosen for the urban and rural sample respectively. The sample size was equally divided between the urban and rural population group.

\subsection{Sampling Technique}

A total of 534 out of 871,526 married women of child bearing age group (15 - 49 
years) participated in this study [8]. EPi Info version 7 was used to calculate the sample size, entering an average estimate of unmet need for family planning $13 \%$ with 95\% confidence level. Accordingly, the sample size was estimated and the number was duplicated to increase the power of the study and guard against non-respondent's rate.

The selected areas (rural/urban), were divided into four blocks (North, East, South, and West). Two areas (of four) were selected randomly. Starting from a noticeable landmark, all consecutive households in each area were sampled until 267 women meeting the inclusion criteria of the study were selected in each area.

\subsection{Data Collection}

Data have been collected by face to face interviews using a structured and pretested questionnaire, including questions about socio-demographic data, and contraceptive practices.

\subsection{Statistical Methods}

The Statistical Package for Social Science (SPSS) for Windows (version 19.0) for statistical analysis was used. Quantitative data were presented by mean and standard deviation, while qualitative data were presented by frequency distribution. Chi-square test was used to compare between more than one proportion and Independent sample $t$ test was used to compare between two means. Binary logistic regression analysis was performed to determine the independent factors that affect the unmet need of family planning. A statistically significant level was considered when $P$ value was less than 0.05 .

\subsection{Ethical Considerations}

Ethical approval was taken by the ethical committee of the Faculty of Medicine, Minia University. Prior to data collection, informed consents were obtained from all participants after supplying comprehensive information about the nature of the study.

\section{Results}

Of the 534 participants, 365 women $(66.7 \%)$ were currently using a contraceptive method, 147 (41.3\%) for spacing, and 209 (58.7\%) for limiting. Of the 178 women not using contraception, $72(40.4 \%)$ were pregnant or in puerperium. Mistimed and unwanted pregnancies were reported by $9.7 \%$ and $6.9 \%$ of pregnant or postpartum women, respectively, and 4 (5.6\%) of pregnancies were due to failed contraception. Of the 106 women not using a contraceptive methods and who were not pregnant or in puerperium, 50 (47.2\%) were trying to conceive, $44(41.5 \%)$ wished to limit their childbearing and $12(11.3 \%)$ wished to space their childbearing. Thus 68 of all currently married women were identified as having an unmet need for contraception, giving a prevalence rate of $12.7 \%$. Of these, $19(27.9 \%)$ wished to space their childbearing, and $49(72.1 \%)$ wished to 


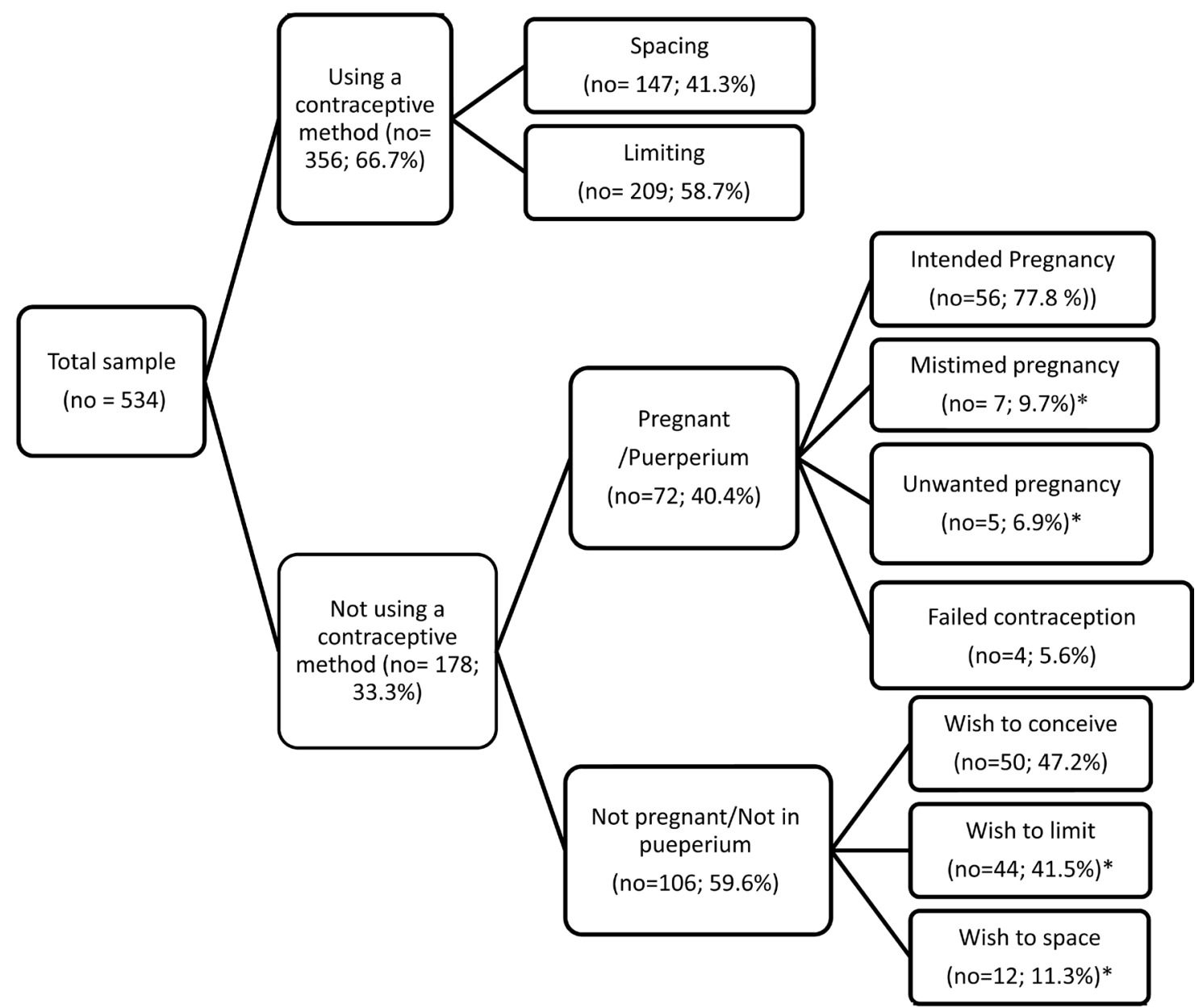

N.B. * women who were identified as having an unmet need for contraception.

Figure 1. Flow chart distribution of the studied women according to their family planning characteristics.

limit their childbearing (Figure 1).

The socio-demographic characteristics of the studied females are shown in (Table 1). About two-thirds (63.2\%) of women with unmet need were above age of 35 years old compared to $33.5 \%$ of women who currently used contraceptive methods. Women with unmet need had a significantly larger number of children ( $4.3 \pm 3.19$ vs $3.04 \pm 2.62)$, and more female offsprings ( $2.6 \pm 2.93$ vs $1.5 \pm 1.24)$. There was a statistically significant difference between women with unmet need and those without regarding the level of education of both wife and husband. Women with contraceptive met need have been educated, similarly to their husbands, from secondary to university level, compared to women with unmet contraceptive need who are mainly illiterate women married to illiterate husbands.

There was a significant difference between rural and urban women regarding causes of unmet needs of contraception. About $34.2 \%$ of rural women compared to $10 \%$ of urban women reported that opposition to contraception by husband was the cause of not using contraception. However, other causes of unmet need were not statistically different between urban and rural residents. The concerns about side effects followed by infrequent sexual activity were mostly reported by 
urban women (Table 2).

Regarding socio-demographic determinants of unmet need, the results of multivariable logistic regression shows that, women whose age $>35$ years old were about three times (adjusted OR $=2.88,95 \%$ CI: $1.13-7.35$ ) more likely to have unmet need for FP compared to younger women. Furthermore, increasing numbers of live births and number of female offspring were associated with increased the unmet need of contraception with OR (adjusted OR $=1.32,95 \% \mathrm{CI}$ :

Table 1. Socio-demographic characteristics of the studied women.

\begin{tabular}{|c|c|c|c|}
\hline Variables & $\begin{array}{l}\text { Women with met need } \\
\text { of contraception } \\
\mathrm{N}=466\end{array}$ & $\begin{array}{l}\text { Women with unmet need } \\
\text { of contraception } \\
N=68\end{array}$ & P-value \\
\hline \multicolumn{4}{|l|}{ Residence } \\
\hline Urban & $237(50.9 \%)$ & $30(41.1 \%)$ & 0.3 \\
\hline Rural & $229(49.1 \%)$ & $38(55.9 \%)$ & \\
\hline \multicolumn{4}{|l|}{ Age (years) } \\
\hline$<25$ years old & $95(20.4 \%)$ & $7(10.3 \%)$ & 0.0001 \\
\hline 25 - 35 years old & $215(46.1 \%)$ & $18(26.5 \%)$ & \\
\hline$>35$ years old & $156(33.5 \%)$ & $43(63.2 \%)$ & \\
\hline Age at marriage & $20.2 \pm 3.82$ & $20.3 \pm 3.60$ & 0.9 \\
\hline Total number of live births & $3.04 \pm 2.62$ & $4.3 \pm 3.19$ & 0.0001 \\
\hline Total number of male offspring & $1.6 \pm 2.19$ & $1.7 \pm 1.21$ & 0.6 \\
\hline Total number of female offspring & $1.5 \pm 1.24$ & $2.6 \pm 2.93$ & 0.003 \\
\hline Age of last child & $4.9 \pm 5.18$ & $6.4 \pm 5.99$ & 0.06 \\
\hline Number of dead children & $0.27 \pm 0.88$ & $0.43 \pm 1.16$ & 0.2 \\
\hline \multicolumn{4}{|l|}{ History of abortion } \\
\hline Absent & $354(76.0 \%)$ & $50(73.5 \%)$ & 0.6 \\
\hline Present & $112(24.0 \%)$ & $18(26.5 \%)$ & \\
\hline \multicolumn{4}{|l|}{ Women's occupation } \\
\hline Housewife & $329(70.6 \%)$ & $50(73.5 \%)$ & 0.6 \\
\hline Works & $137(29.4 \%)$ & $18(26.5 \%)$ & \\
\hline \multicolumn{4}{|l|}{ Women's education } \\
\hline Illiterate & $91(19.5 \%)$ & $23(33.8 \%)$ & 0.005 \\
\hline Read and write/or Primary & $86(18.5 \%)$ & $18(26.5 \%)$ & \\
\hline Secondary & $172(36.9 \%)$ & $15(22.1 \%)$ & \\
\hline University/above & $117(25.1 \%)$ & $12(17.6 \%)$ & \\
\hline \multicolumn{4}{|l|}{ Husband's education } \\
\hline Illiterate & $67(14.4 \%)$ & $19(27.9 \%)$ & 0.01 \\
\hline Read and write/or Primary & $118(25.3 \%)$ & $20(29.4 \%)$ & \\
\hline Secondary & $153(32.8 \%)$ & $18(26.5 \%)$ & \\
\hline University/above & $128(27.5 \%)$ & $11(16.2 \%)$ & \\
\hline
\end{tabular}


Table 2. Reported causes of unmet needs of contraception among studied women.

\begin{tabular}{|c|c|c|c|}
\hline Variables & $\begin{array}{l}\text { Urban women } \\
(\text { no }=30)\end{array}$ & $\begin{array}{l}\text { Rural women } \\
\text { (no }=38)\end{array}$ & P-value \\
\hline Opposition to contraception by husband & $3(10)$ & $13(34.2)$ & 0.04 \\
\hline Woman own opposition to contraception & $1(3.3)$ & $2(5.3)$ & 0.8 \\
\hline $\begin{array}{l}\text { Woman concern about side effects and } \\
\text { health risks associated with use }\end{array}$ & $12(40)$ & $8(21.1)$ & 0.1 \\
\hline Infrequent sex & $10(33.4)$ & $8(21.1)$ & 0.3 \\
\hline little perceived possibility of pregnancy & $2(6.7)$ & $4(10.5)$ & 0.9 \\
\hline High cost of contraception & $1(3.3)$ & $2(5.2)$ & 0.8 \\
\hline Access-related problem & $1(3.3 \%)$ & $1(2.6)$ & 0.5 \\
\hline
\end{tabular}

Table 3. Factors associated with unmet contraceptive need among studied women.

\begin{tabular}{|c|c|c|}
\hline Variables & OR $(95 \% \mathrm{CI})$ & $P$ value \\
\hline \multicolumn{3}{|l|}{ Residence } \\
\hline Urban & (reference) & \\
\hline Rural & $1.35(0.72-2.52)$ & 0.3 \\
\hline \multicolumn{3}{|l|}{ Age } \\
\hline$<25$ years old & (reference) & \\
\hline 25 - 35 years old & $0.84(0.30-2.35)$ & 0.7 \\
\hline$>35$ years old & $2.88(1.13-7.35)$ & 0.02 \\
\hline \multicolumn{3}{|l|}{ Women's education } \\
\hline Illiterate & (reference) & \\
\hline Read and write & $0.91(0.41-2.02)$ & 0.8 \\
\hline Basic & $0.34(0.09-1.26)$ & 0.1 \\
\hline Secondary & $0.57(0.18-1.86)$ & 0.3 \\
\hline University/above & $0.49(0.21-1.16)$ & 0.1 \\
\hline \multicolumn{3}{|l|}{ Women's occupation } \\
\hline Works & (reference) & \\
\hline Housewife & $1.30(0.66-2.49)$ & 0.4 \\
\hline Age at marriage & $0.99(0.91-1.08)$ & 0.8 \\
\hline Number of children & $1.32(1.04-1.67)$ & 0.02 \\
\hline Number of male children & $0.79(0.89-1.12)$ & 0.1 \\
\hline Number of female children & $1.37(1.09-1.65)$ & 0.004 \\
\hline Number of abortions & $1.27(0.95-1.68)$ & 0.09 \\
\hline Number of dead children & $1.07(0.79-1.46)$ & 0.6 \\
\hline \multicolumn{3}{|l|}{ Husband attitude } \\
\hline Supportive & (reference) & \\
\hline None-supportive & $2.96(1.53-5.72)$ & 0.001 \\
\hline
\end{tabular}

$1.04-1.67$ ) and (adjusted OR $=1.37,95 \%$ CI: $1.09-1.65$ ), respectively. Also, it was found that the non-supportive attitude of husband was a significant predictor of non-use of contraceptive methods (adjusted OR $=2.96,95 \%$ CI: 1.53 5.72) (Table 3). 


\section{Discussion}

In the current study, it was found that the level of unmet contraceptive need was $12.7 \%$ which is nearly the same as the national level reported by the DHS data for Egypt (13\%) in 2014 [9]. This level was slightly higher than the level of unmet need reported by previous demographic health survey 2008 [10], this difference was due to the use of revised unmet need definition which was developed and adopted in 2012 [2]. However, it was lower than those reported by Umbeli et al. in Sudan, 30.7\% [11] and by Yadav et al. in India, 17.5\% [12].

In the present study, $27.9 \%$ of this need reflected a desire to postpone the next birth, and the remainder $(72.1 \%)$ represented an interest in limiting births (Figure 1), this was comparable to that found by EDHS, where almost two-thirds of all unmet need was for family limitation [9].

Likewise Egyptian studies conducted in Cairo [13] and Upper Egypt; El Fayoum and Benisuef governorates [14] age of the woman as a determinant of unmet need was found to be significant, the relationship between a woman's age and her unmet need changed across the reproductive age. Although unmet need decreased with the years of life below the age of 35 years, it increased with age 35 years or more. This was in line with results done in Nepal and Zambia [15] [16]. On contrary, a study among Indian women showed prevalence of unmet need more in younger age groups [17].

Egyptian society particularly in rural areas in Upper Egypt, boys are highly valued over girls, and husbands are the decision-makers in almost all aspects of life, including reproductive choices. This fact was confirmed in this study, significant associations between number of children, number of females offspring and unmet need were identified, as the number of children especially females increased, so did the total unmet need as shown both in univariate and multivariate analysis. Additionally, negative attitude of husbands toward the use of FP methods by their wives was one of the most significant predictors in the multivariate regression model. Similar findings were reported in many studies [13] [14] [18]. In contrast, in an Indian study, none of the study participants reported that their partners interfered with their birth control measures [19].

The current study showed that a woman's higher level of education is associated with a decrease in unmet need which in agreement with Wulifan et al. [20] who reported that woman's education was an important factor persuading her to use family planning methods.

It is important to explore women's reasons for non-use and their perception of their risk for conceiving. Our study findings showed that the opposition to contraception by husband was reported as main cause in rural residence (34.2\%) and reported by $10 \%$ of urban residence. As discussed before, husbands are the decision-makers in almost all aspects of life, including reproductive choices particularly in rural areas in Upper Egypt. A similar finding was reported by Shah et al. (2003) who found that approximately $41 \%$ of women with unmet need said that their husband disapproved of contraceptive [18]. Similar finding reported 
among married women in Burkina Faso [21] and in Cameroon [22]. Unlike in urban areas, people in the rural areas prefer many children because they help them with farming activities.

Concerns about side effects and health risks were cited as the first cause by urban and as the second cause by rural women. This was in line with studies conducted in many countries [23] [24] [25] [26] [27], possibly because more women have had side effects in the past; or they heard about side effects from others.

In the current study $33.4 \%$ and $21 \%$ of urban and rural women respectively, cited infrequent sex as a reason for not using contraception. Data from Egyptian DHS revealed that fertility related causes such as having little or no sex was responsible for $36.6 \%$ of unmet need [10]. Sedgh et al. (2016) reported that onethird of married women with unmet need in Asia, in Latin America and the Caribbean cite infrequent or no sex as a reason for not using contraception. About one-fifth of African women cite the same reason [28]. The costs of methods and accessibility to a source have remained uncommon reasons for nonuse.

\section{Conclusion}

This study demonstrates that there is a noticeable proportion of women in Upper Egypt have an unmet need for contraception, which increases by the increase of reproductive age. Thus, FP programs should have a specific focus on older women's need for limiting. Partners can play various roles in supporting or hindering women's FP decisions. The government should improve the counseling approaches integrating participation of both woman and her husband in choices of FP and its methods. The women's perceptions about little possibilities of pregnancy whether because of infrequent sex or other causes and high concern about side effects of contraceptive methods worth greater attention and further research.

\section{References}

[1] Genet, E., Abeje, G. and Ejigu, T. (2015) Determinants of Unmet Need for Family Planning among Currently Married Women in Dangila Town Administration, Awi Zone, Amhara Regional State; A Cross Sectional Study. Reproductive Health, 12, 1-5. https://doi.org/10.1186/s12978-015-0038-3

[2] Bradley, E., Croft, T., Fishel, J. and Westoff, C. (2012) Revising Unmet Need for Family Planning. DHS Analytical Studies No. 25. ICF International, Calverton.

[3] Singh, S., Darroch, J.E. and Ashford, L.S. (2014) Adding It Up: The Costs and Benefits of Investing in Sexual and Reproductive Health 2014, Guttmacher Institute, New York.

[4] Ojakaa, D. (2008) Trends and Determinants of Unmet Need for Family Planning in Kenya. DHS Working Papers No. 56. Macro International, Inc., Calverton.

[5] Pasha, O., Fikree, F. and Vermund, S. (2001) Determinants of Unmet Need for Family Planning in Squatter Settlements in Karachi, Pakistan. Asia-Pacific Population Journal, 16, 93-108.

[6] Ross, J.A. and Winfrey, W.L. (2002) Unmet Need for Contraception in the Devel- 
oping World and the Former Soviet Union: An Updated Estimate. International Family Planning Perspectives, 28, 138-143. https://doi.org/10.2307/3088256

[7] Eltomy, E.M., Saboula, N.E. and Hussein, A.A. (2013) Barriers Affecting Utilization of Family Planning Services among Rural Egyptian Women. EMHJ, 19, 400-408.

[8] State Information Service (2016) Egypt: Population, Minia. www.sis.gov.eg/Story/99697?lang=en-us

[9] El-Zanaty, F. (2014) Egypt Demographic and Health Survey. Ministry of Health and Population, El-Zanaty and Associate and the DHS Program ICF International, Rockville, Maryland.

[10] El-Zanaty, F. and Way, A. (2009) Egypt Demographic and Health Survey 2008. Ministry of Health and Population, Calverton, Maryland.

[11] Umbeli, T., Mukhtar, A. and Abusalab, M. (2005) Study of Unmet Need for Family Planning in Dar Assalam, Sudan 2001. EMHJ, 11, 594-600.

[12] Yadav, K., Singh, B. and Goswami, K. (2009) Unmet Family Planning Need: Differences and Levels of Agreement between Husband-Wife, Harana, India. Indian Journal of Community Medicine, 34, 188-191. https://doi.org/10.4103/0970-0218.55281

[13] Sultan, K., Bakr, I., Ismail, A. and Arafa, N. (2010) Prevalence of Unmet Contraceptive Need among Egyptian Women. A Community-Based Study. Journal of Preventive Medicine and Hygiene, 51, 62-66.

[14] Metwally, A., Saleh, R., Abdelhamed, A., Salama, S., Mores, C., Shaaban, F. and Azmy, O. (2015) Determinants of Unintended Pregnancy and Its Impact on the Health of Women in Some Governorates of Upper Egypt. Journal of the Arab Society for Medical Research, 10, 1-8. https://doi.org/10.4103/1687-4293.159368

[15] Paudel, I. and Budhathoki, S. (2011) Unmet Needs for Family Planning in Sunsari Eastern Nepal. Health Renaiss, 9, 148-151. https://doi.org/10.3126/hren.v9i3.5581

[16] Imasiku, E., Odimegwu, C., Adedini, S. and Ononokpono, D. (2014) Variations in Unmet Need for Contraception in Zambia. Does Ethnicity Play a Role? Journal of Biosocial Science, 46, 294-315. https://doi.org/10.1017/S0021932013000357

[17] Relwani, N., Saoji, A., Kulkarni, M., Kasturwar, N., Zade, R. and Wadke, R. (2015) Revealing Unmet Need for Contraception among Married Women in an Urban Slum of Nagpur. International Journal of Medical Science and Public Health, 4, 1136-1140. https://doi.org/10.5455/ijmsph.2015.11032015247

[18] Shaha, M., Shahb, N. and Menonb, I. (2003) Unmet Need for Contraception in Kuwait: A Developing Country without a Family Planning Program. International Journal of Gynecology and Obstetrics, 83, 335-338. https://doi.org/10.1016/S0020-7292(03)00161-9

[19] Prateek, S. and Saurabh, R. (2012) Contraceptive Practices Adopted by Women Attending an Urban Health Center. African Health Sciences, 12, 416-421.

[20] Wulifan, J., Brenner, S., Jahn, A. and De Allegri, M. (2016) A Scoping Review on Determinants of Unmet Need for Family Planning among Women of Reproductive Age in Low and Middle Income Countries. BMC Women's Health, 16, 1-15.

[21] Adebowale, S. and Palamuleni, M. (2014) Determinants of Unmet Need for Modern Contraception and Reasons for Non-Use among Married Women in Rural Areas of Burkina Faso. African Population Studies, 28, 499-513. https://doi.org/10.11564/28-1-503

[22] Ajong, Y., Njotang, P., Yakum, M., Essi, M., Essiben, F., Eko, F., Kenfack, B. and Mbu, E. (2016) Determinants of Unmet Need for Family Planning among Women 
in Urban Cameroon: A Cross Sectional Survey in the Biyem-Assi Health District. BMC Women's Health, 16, 4. https://doi.org/10.1186/s12905-016-0283-9

[23] Casterline, J. and Sinding, S. (2000) Unmet Need for Family Planning in Developing Countries and Implications for Population Policy. Population and Development Review, 26, 691-723. https://doi.org/10.1111/j.1728-4457.2000.00691.x

[24] Shah, M.A., Shah, N.M., Chowdhury, R.I., et al. (2004) Unmet Need for Contraception in Kuwait: Issues for Health Care Providers. Social Science \& Medicine, 59, 1573-1580. https://doi.org/10.1016/j.socscimed.2004.01.033

[25] Campbell, M., Nuriye, N.S. and Malcolm, P. (2006) Barriers to Fertility Regulation. A Review of the Literature. Studies in Family Planning, 37, 87-98. https://doi.org/10.1111/j.1728-4465.2006.00088.x

[26] Hall, M.A., Stephenson, R.B. and Juvekar, S. (2008) Social and Logistical Barriers to the Use of Reversible Contraception among Women in a Rural Indian Village. Journal of Health, Population and Nutrition, 26, 241-250.

[27] Cleland, J., Harbison, S. and Shah, I.H. (2014) Unmet Need for Contraception: Issues and Challenges. Studies in Family Planning, 45, 105-122.

https://doi.org/10.1111/j.1728-4465.2014.00380.x

[28] Sedgh, G., Ashford, L. and Hussain, R. (2016) Unmet Need for Contraception in Developing Countries: Examining Women's Reasons for Not Using a Method. Guttmacher Institute, New York.

https://www.guttmacher.org/fact-sheet/unmet-need-for-contraception-in-developin g-countries 